Old Dominion University

ODU Digital Commons

Bioelectrics Publications

Frank Reidy Research Center for Bioelectrics

6-2002

\title{
Effect of Electrically Mediated Intratumor and Intramuscular Delivery of a Plasmid Encoding IFN a on Visible B16 Mouse Melanomas
}

Loree C. Heller

Old Dominion University, lheller@odu.edu

Stephanie F. Ingram

M. Lee Lucas

Richard A. Gilbert

Richard Heller

Old Dominion University, rheller@odu.edu

Follow this and additional works at: https://digitalcommons.odu.edu/bioelectrics_pubs

Part of the Biotechnology Commons, $\underline{\text { Genetics Commons, and the Oncology Commons }}$

\section{Repository Citation}

Heller, Loree C.; Ingram, Stephanie F.; Lucas, M. Lee; Gilbert, Richard A.; and Heller, Richard, "Effect of Electrically Mediated Intratumor and Intramuscular Delivery of a Plasmid Encoding IFN $\alpha$ on Visible B16 Mouse Melanomas" (2002). Bioelectrics Publications. 108.

https://digitalcommons.odu.edu/bioelectrics_pubs/108

\section{Original Publication Citation}

Heller, L. C., Ingram, S. F., Lucas, M. L., Gilbert, R. A., \& Heller, R. (2002). Effect of electrically mediated intratumor and intramuscular delivery of a plasmid encoding IFN $\alpha$ on visible B16 mouse melanomas. Technology in Cancer Research Treatment, 1(3), 205-209. doi:10.1177/153303460200100305 


\section{Effect of Electrically Mediated Intratumor and Intramuscular Delivery of a Plasmid Encoding IFN $\alpha$ on Visible B16 Mouse Melanomas}

www.tcrt.org

Interferon $\alpha$ may be used as a single agent therapy for metastatic malignant melanoma or as an adjuvant to chemotherapy. Delivery of interferon $\alpha$ by gene therapy offers an alternative to recombinant protein therapy. Electrically mediated delivery enhances plasmid expression in a number of tissues, for instance skin, liver, muscle and tumors including melanomas. Here we compare the effect of delivery of a plasmid encoding mouse interferon $\alpha$ on growth of visible B16 mouse melanomas following electrically mediated delivery to muscle or directly to the tumor. Intratumoral delivery of interferon $\alpha$ plasmid not only slows melanoma growth, but induces complete, long term, regression. This effect was not observed after intramuscular delivery.

\section{Introduction}

A variety of clinical trials have investigated interferon $\alpha$ (IFN $\alpha$ ) as a single agent therapy or as an adjuvant to chemotherapy for metastatic malignant melanoma $(1,2)$. IFN $\alpha$ treatment increases patient survival and durability of cure. In the B16 mouse melanoma model, long term in vitro exposure of cells to IFN $\alpha$ increases mouse survival after injection and delays tumor growth (3). When B16 cells are irradiated and used as a vaccine, a significant level of protection is elicited which prevents tumor establishment (4). IFN $\alpha$ producing clones are less tumorigenic, although mice immunized with irradiated cells are only slightly protected (5).

Delivery of IFN $\alpha$ by gene therapy offers an alternative to recombinant protein therapy. In vivo electroporation, which has been used in phase II clinical trials for the delivery of chemotherapeutic agents to cancer tumors $(6,7)$ also enhances plasmid delivery and expression $(8,9)$. The electrically mediated enhancement of plasmid expression has been demonstrated in skin (10-12), liver (13), and muscle (14-19). Intramuscular electroporation delivery of a plasmid encoding IFN $\alpha$ has been used to affect growth of squamous cell carcinomas in mice (20).

Electrically mediated enhancement of plasmid expression following direct intratumor injection of reporter plasmid has been demonstrated in rat brain tumors (21), mouse melanomas (22), and rat liver tumors (23). Therapeutic responses to experimental melanomas have also been described following electrically mediated delivery of a dominant negative Stat3 variant in mouse melanomas (24) or combinations of cytokines such as interleukins 2 and 12 (25) or interleukins 12 and 18 (26). The combination of electrochemotherapy and cytokine plasmid delivery by electroporation into melanomas prevents tumor recurrence and induces long-term antitumor immunity in mice (27).
Loree C. Heller, Ph.D. ${ }^{*}$ Stephanie F. Ingram, B.S. ${ }^{2}$ M. Lee Lucas, Ph.D. ${ }^{2}$ Richard A. Gilbert, Ph.D. ${ }^{3}$ Richard Heller, Ph.D. ${ }^{2}$

${ }^{1}$ University of South Florida

Center for Molecular Delivery c/o Department of Surgery MDC16 12901 Bruce B. Downs Blvd. Tampa, FL 33612

${ }^{2}$ Department of Surgery MDC 16 12901 Bruce B. Downs Blvd.

Tampa, FL 33612

${ }^{3}$ College of Engineering 4202 E. Fowler Ave.

Tampa, FL 33620
* Corresponding Author: Loree C. Heller, Ph.D. Email: 1heller@hsc.usf.edu 
Simple muscle injection of a plasmid encoding IFN $\alpha$ is effective in reducing the onset of growth of B16 melanomas and in increasing mouse survival (28). Here we directly compare the effect on growth of visible B16 mouse melanomas following electrically mediated delivery to muscle or directly to the tumor. Direct intratumoral delivery of plasmid not only slows melanoma growth, but induces complete, long term, regression. This effect was not observed after intramuscular delivery.

\section{Materials and Methods}

\section{Plasmids}

Plasmids VR1255, encoding the luciferase gene driven by the CMV promoter, and VR4111, encoding mouse interferon $\alpha$ (28, Vical, San Diego, CA), were prepared using an endotoxin-free method (Qiagen, Valencia, CA), suspended in sterile injectable saline, and endotoxin levels confirmed to be less than 0.1 EU/ug (QCL-1000, Biowhittaker, Walkersville, MD).

\section{Cell culture and tumor induction}

B16.F10 (ATCC CRL-6475) mouse melanoma cells were maintained in McCoys 5A medium supplemented with $10 \%$ fetal bovine serum and $90 \mu \mathrm{g} / \mathrm{ml}$ gentamycin at $37 \mathrm{C}$ and $5 \%$ $\mathrm{CO}_{2}$. A suspension containing $10^{6}$ trypsinized B16 cells (>90\% viability) in $50 \mu \mathrm{l}$ sterile injectable saline was injected subcutaneously in the left flank of 7 week old female C57B1/6 mice (Jackson Laboratory, Bar Harbor, ME) using a 0.5 inch 30 gauge needle. Tumors were allowed to grow 8 days to a diameter of approximately $4 \mathrm{~mm}$ before treatment, equivalent to a volume of approximately $34 \mathrm{~mm}^{3}$. Mice were challenged by subcutaneous injection of $5 \times 10^{5}$ cells on the opposite flank.

\section{Plasmid delivery}

Mice were anesthetized during all treatments using a mixture of $2 \%$ isoflurane and $98 \% \mathrm{O}_{2}$.

Tumors. Tumors were injected with $50 \mu \mathrm{l} 2 \mu \mathrm{g} / \mu \mathrm{l}$ plasmid DNA unless otherwise noted, then pulsed immediately with six rotating $100 \mu$ s pulses at a nominal field strength of $1500 \mathrm{~V} / \mathrm{cm}$ and a frequency of $1 \mathrm{~Hz}$ with a $7.5 \mathrm{~mm}$ diameter 6 needle electrode (29).

Muscle. Left and right gastrocnemius muscles were alternately injected weekly with $50 \mu \mathrm{l} 2 \mu \mathrm{g} / \mu \mathrm{l}$ VR4111 plasmid. If treated with electroporation, three $20 \mathrm{~ms}$ pulses per tissue area were applied immediately at a nominal field strength of $100 \mathrm{~V} / \mathrm{cm}$ with a custom applicator containing 4 needle electrodes in a $2.5 \times 5 \mathrm{~mm}$ rectangle (30). All pulses were delivered using a T820 Electrosquare porator (BTX, San Diego, CA).

\section{Tumor monitoring}

Tumors were measured twice weekly using a digital caliper. Tumor volume was calculated by the standard formula $v=a b^{2} / 6$, where $a$ is the longest diameter, and $b$ is the next longest diameter perpendicular to $a$. In the case of continued tumor growth or tumor recurrence, the animal was considered incurable and humanely euthanized when the tumor volume reached $1000 \mathrm{~mm}^{3}$. Each individual tumor volume was normalized to its tumor volume on day 0 , the first day of treatment.

ELISAs

For determination of IFN $\alpha$ levels after intramuscular delivery, blood was removed from animals via the tail vein, allowed to clot at $4^{\circ} \mathrm{C}$, then the serum removed. For determination of IFN $\alpha$ levels after intratumor delivery, tumors were induced and treated as described, then mice were humanely euthanized at set times after treatment as indicated. Tumors were removed, weighed, homogenized in PBS containing protease inhibitors (P8340, Sigma-Aldrich, St. Louis, MO), and centrifuged at $1000 \times \mathrm{g}$ for 5 minutes. Serum and tumor supernatants were assayed for IFN $\alpha$ production by ELISA (PBL Biomedical Laboratories, New Brunswick, New Jersey).

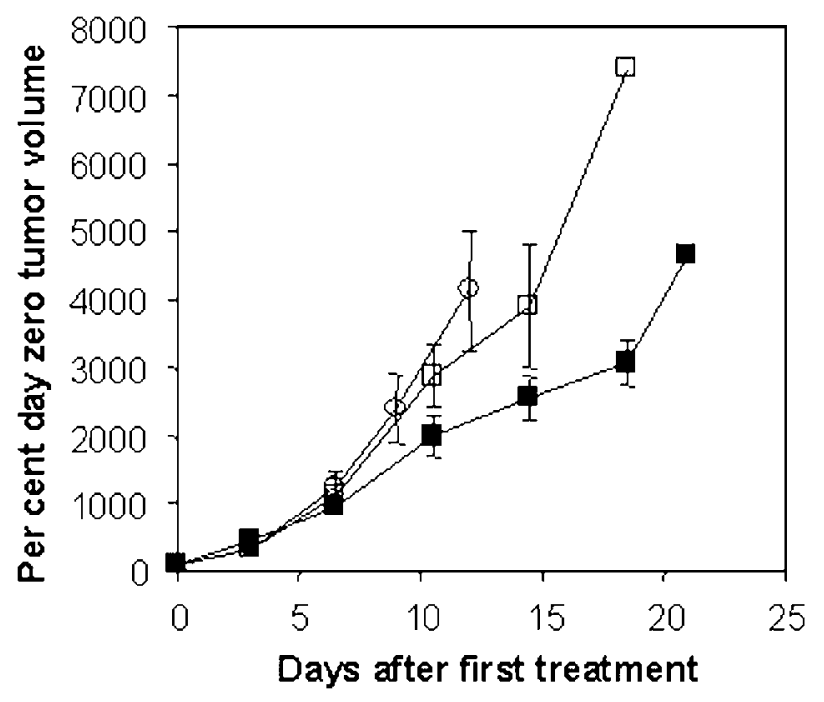

Figure 1: Effect of intramuscular delivery of plasmid encoding interferon $\alpha$ (VR4111) on growth of large, visible B16 mouse melanomas. Tumors were induced, $100 \mu \mathrm{g}$ plasmid VR4111 was delivered intramuscularly with or without electroporation, and tumor growth monitored as described in methods. Lines represent mean and standard error of the mean. $O$, no treatment, $\mathrm{n}=6$; $\square$, IM VR4111 injection only, $\mathrm{n}=7$; $\mathbf{\square}$, IM VR4111 with pulses as described in methods, $\mathrm{n}=7$.

\section{Results and Discussion}

The effect of intramuscular delivery of VR4111, encoding IFN $\alpha$, on B16 tumor growth was initially assessed (Figure 1). 
Previously, intramuscular injection of $100 \mu \mathrm{g}$ VR4111 at 1 week intervals has been shown to successfully slow the onset of B16 melanomas (28). Here, B16 cells were injected and tumors allowed to grow 8 days to an average diameter of $4 \mathrm{~mm}$ (day 0). Animals received three weekly treatments of 100 ug plasmid in alternating gastrocnemius muscles with or without electric pulses as described in methods. Tumors in the treated groups were compared to tumors from animals that received no treatment and continued to grow. In the groups that received injection of plasmid only or injection of plasmid followed by electric pulses, resulting in much higher levels of systemic IFN $\alpha$ expression, no significant effect was seen on tumor growth. However, a significant effect on survival was observed $(\mathrm{p}<0.005)$ in the group receiving intramuscular IFN $\alpha$ plasmid and electroporation when compared to untreated animals or to animals receiving plasmid injection alone. This study differs from the study by Horton et. al. (28) in that treatment began 8 days after injection of $10^{6}$ cells rather than 3 days after injection of $10^{4}$ cells, so the tumors were much larger when treatment began. This may explain the ineffectiveness of intramuscular treatment in this case.

Direct tumor delivery of VR4111 was more effective than intramuscular delivery in inducing B16 tumor regression (Figure 2a). Tumors were induced and allowed to grow as above, then treated with electrically mediated delivery of 100 ug control vector (VR1255). This treatment insignificantly slowed tumor growth. Electrically mediated delivery of VR4111 slowed tumor growth and induced long term complete regressions in a dose dependent manner. After delivery of 100 ug plasmid, 5 of 7 tumors regressed completely, after 50 ug, 3 of 7 regressed completely, and after delivery of 25 ug plasmid, 2 of 7 regressed completely (Figure 2b). These regressions lasted 75 days until the animals were challenged subcutaneously. Five of the 10 tumor free animals were resistant to subcutaneous challenge, while tumors grew in naive control animals, indicating that some antitumor immunity was generated.

Different electroporation parameters and electrodes were used for intratumor or intramuscular delivery. Interestingly, these different delivery methods and sites resulted in similar peak serum levels of IFN $\alpha$, although the time course of expression differed (Figure 3). Serum expression peaked at day 1 following intratumor delivery and decreased immediately, while serum expression after intramuscular delivery peaked more slowly at day 4 and decreased more gradually. Since the tumors were large and B16 melanoma is particularly aggressive, the faster increase in serum IFN $\alpha$ levels observed after intratumor delivery may be more effective in inhibiting tumor growth.

Since intratumor delivery was effective therapeutically, tumor levels of IFN $\alpha$ after intratumor delivery were determined (Figure 4). No IFN $\alpha$ expression was noted after
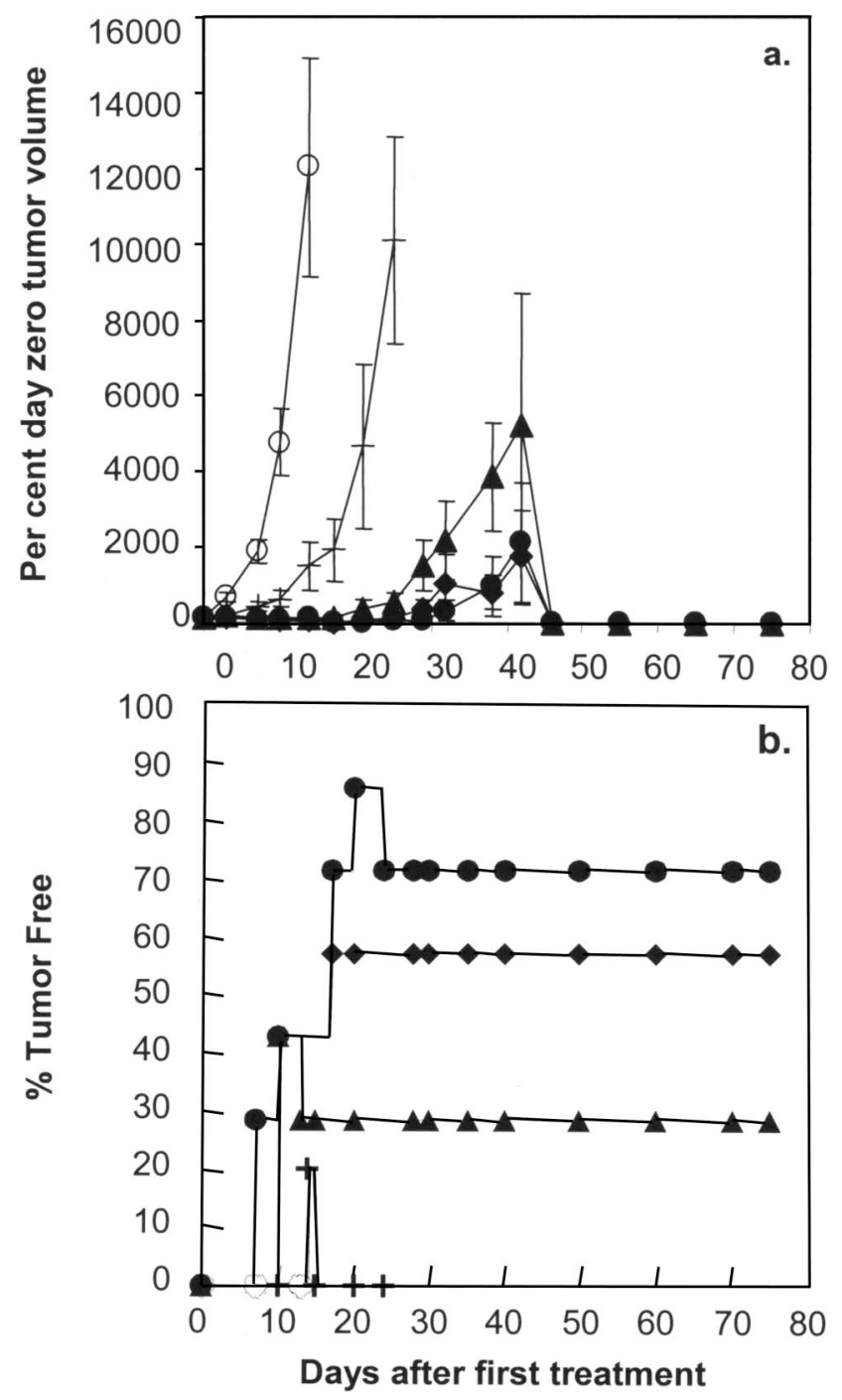

Figure 2: Effect of intratumor delivery of plasmid encoding interferon $\alpha$ (VR4111) on growth of large, visible B16 mouse melanomas. Tumors were induced, the indicated amount of VR4111 or VR1255 (luciferase control) plasmid DNA was delivered intratumorally in a $50 \mu \mathrm{l}$ volume with or without electroporation, and tumor growth monitored as described in methods. Lines represent mean and standard error of the mean. (a) Tumor volume. The large drop in tumor volume at day 42 after initial treatment is due to euthanization of animals with large tumors, leaving tumor free animals (see Figure 2b). (b) Per cent tumor free animals. Subcutaneous challenge was preformed at day 74 after the first treatment and animals followed for 50 days. $O$, no treatment; +, VR1255 (luciferase encoding plasmid with pulses as described in methods; $\boldsymbol{\Delta}, 25 \mu \mathrm{g}$ VR4111 with pulses; $\$ 50 \mu \mathrm{g}$ VR4111 with pulses; $\bullet, 100 \mathrm{mg}$ VR4111 with pulses.

injection alone of VR4111 or after electrically mediated delivery of a plasmid encoding luciferase (VR1255, data not shown). Intratumor IFN $\alpha$ expression increased significantly after electrically mediated delivery of VR4111, peaking at $369 \mathrm{pg} / \mathrm{mg}(369 \mathrm{ng} / \mathrm{g})$ tumor at day 1 while serum levels peaked approximately 575 fold lower at $643 \mathrm{pg} / \mathrm{ml}$ serum. This high level of intratumor expression may be responsible for the significant antitumor effect. 


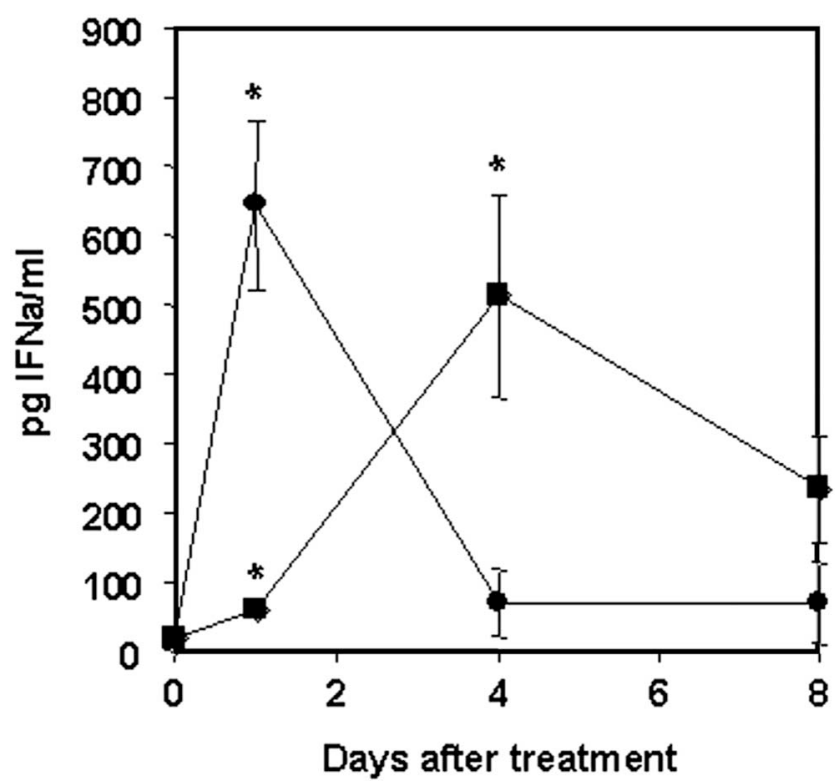

Figure 3: Systemic levels of interferon $\alpha$ after electrically mediated delivery of plasmid DNA. IFN $\alpha$ production time course in B16 melanomas with and without in vivo electroporation. $100 \mu \mathrm{g}$ VR4111 was delivered intramuscularly or intratumorally with electroporation as described in methods. At days $0,1,4$, and 8 , serum was assayed for IFN $\alpha$ production by ELISA $(\mathrm{n}=3)$. $\bullet$, intratumor delivery; $\boldsymbol{\square}$, intramuscular delivery. Bars represent the mean and standard error of the mean. Statistical significance $(\mathrm{p}<0.05)$, relative to injection alone is noted by an asterisk.

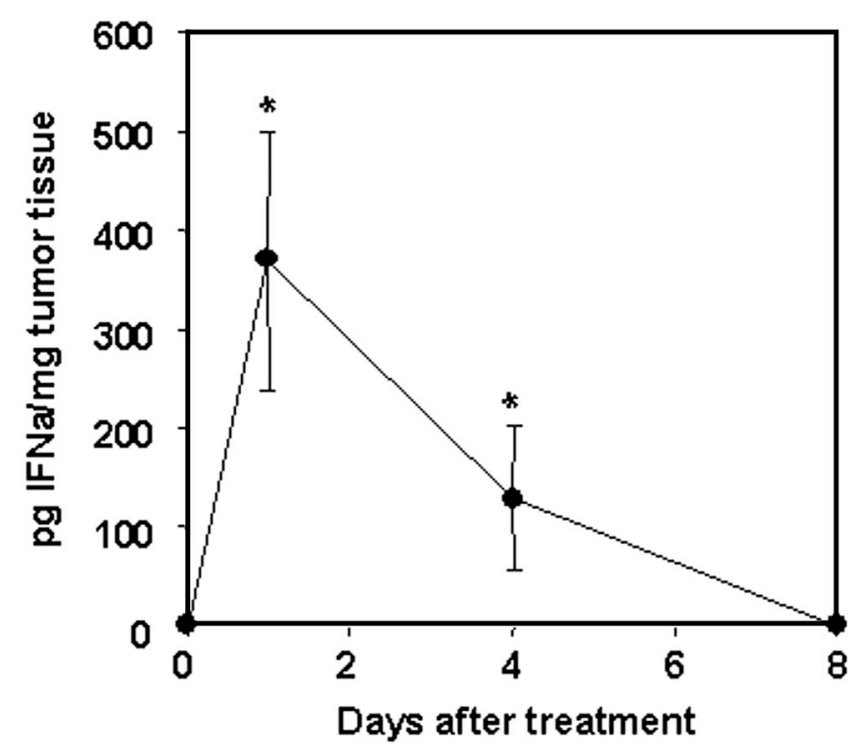

Figure 4: Intratumoral levels of interferon $\alpha$ after electrically mediated delivery of plasmid DNA. $100 \mu \mathrm{g}$ VR4111 was delivered intratumorally with electroporation as described in methods. At days $0,1,4$, and 8 , animals were humanely euthanized, and tumors assayed for IFN $\alpha$ production by ELISA $(n=3)$. Bars represent the mean and standard error of the mean. Statistical significance $(\mathrm{p}<0.05)$, relative to injection alone is noted by an asterisk.
Intramuscular delivery of plasmids encoding IFN $\alpha$ significantly affects the growth of squamous cell carcinomas (20) and B16 melanomas (28). The data here indicate that, while intramuscular delivery of VR4111 does result in serum expression of IFN $\alpha$ and significantly increases survival, delivery by this method has little effect on the growth of visible experimental B16 melanomas. When tumors are accessible, delivery of VR4111 directly to the tumor appears to be a much more effective treatment method, inducing tumor regression and some level of resistance to challenge with B16 cells.

\section{Acknowledgements}

The T820 Electrosquare porator and autoswitcher and plasmids VR1255 and VR4111 were kind gifts of BTX (San Diego, CA) and Vical, Inc. (San Diego, CA) respectively. This research was paid for in part by a University of South Florida Research and Creative Scholarship grant and in part by the Center for Molecular Delivery.

\section{References and Footnotes}

1. Legha, S. S. The Role of Interferon Alfa in the Treatment of Metastatic Melanoma, Semin. Oncol. 24, S4-24-S4-31 (1997).

2. Agarwala, S. S. and Kirkwood, J. M. Adjuvant Therapy of Melanoma, Semin. Surg. Oncol. 14, 302-310 (1998).

3. Fleischmann, C. M., Stanton, G. J., and Fleischmann, W. R., Jr. Enhanced in vivo Sensitivity to Interferon with in vitro Resistant B16 Tumor Cells in Mice, Cancer Immunol. Immunother. 39, 148154 (1994).

4. Wu, T. Y. and Fleischmann, W. R., Jr. Efficacy of B16 Melanoma Cells Exposed in vitro to Long-Term IFN- $\alpha$ Treatment (B16 $\alpha$ Cells) as a Tumor Vaccine in Mice, J. Interferon Cytokine Res. 18, 829-839 (1998).

5. Kaido, T., Bandu, M.-T., Maury, C., Ferrantini, M., Belardelli, F, and Gresser, I. IFN- $\alpha 1$ Gene Transfection Completely Abolishes the Tumorigenicity of Murine B16 Melanoma Cells in Allogeneic DBA/2 Mice and Decreases Their Tumorigenicity in Syngeneic C57BL/6 Mice, Int. J. Cancer 60, 221-229 (1995).

6. Jaroszeski, M. J., Gilbert, R., Heller, R. Electrochemotherapy: An emerging drug delivery method for the treatment of cancer, Adv. Drug Del. Rev. 26, 185-197 (1997)

7. Heller, R., Gilbert, R., Jaroszeski, M. Clinical applications of electrochemotherapy, Adv. Drug Del. Rev. 35, 119-129 (1999).

8. Somiari, S., Glasspool-Malone, J., Drabick, J. J., Gilbert, R. A., Heller, R., Jaroszeski, M. J., and Malone, R. W. Theory and in vivo application of electroporative gene delivery, Mol. Ther. 2,178-187 (2000).

9. Heller, L. C. and Lucas, M. L. Delivery of plasmid DNA by in vivo electroporation, Gene Ther. and Mol. Biol. 5, 50-55 (2000).

10. Titomirov A. V., Sukharev S, Kistanova E. In vivo electroporation and stable transformation of newborn mice by plasmid DNA, Biochim. Biophys. Acta 1088, 131-134 (1991).

11 Glasspool-Malone, J., Somiari, S., Drabick, J. J., Malone, R. W. Efficient nonviral cutaneous transfection. Mol. Ther. 2, 140-146 (2000).

12. Heller, R., Schultz, J., Lucas, M. L., Jaroszeski, M. J., Heller, L. C., Gilbert, R. A., Moelling, K., and Nicolau, C. Intradermal delivery of IL-12 plasmid DNA by in vivo electroporation, DNA and Cell Biol 20, 21-26 (2001) 
13. Heller, R , Jaroszeski, M., Atkin, A., Moradpour, D., Gilbert, R., Wands, J., and Nicolau, C. In vivo gene electroinjection and expression in rat liver, FEBS Lett 389, 225-228 (1996).

14. Aihara H., Miyazaki J.-I. Gene transfer into muscle by electroporation in vivo, Nat Biotech 6, 867-870 (1998).

15. Mir, L. M., Bureau, M. F., Gehl, J., Rangara, R., Rouy, D., Caillaud, J.-M., Delaere, P., Branellec, D., Schwartz, B., and Scherman, D. High-efficiency gene transfer into skeletal muscle mediated by electric pulses, Proc. Natl. Acad. Sci., USA 96, $4262-4267$ (1999).

16. Mathiesen I. Electropermeabilization of skeletal muscle enhances gene transfer in vivo, Gene Ther. 6, 508-514 (1999).

17. Vicat, J. M., Boisseau, S., Jourdes, P., Laine, M., Wion, D., BoualiBenazzouz, R., Benabid, A. L, and Berger, F. Muscle transfection by electroporation with high-voltage and short-pulse currents provides high-level and long-lasting gene expression, Hum. Gene Ther. 11, 11: 909-916 (2000).

18. Maruyama, H., Sugawa, M., Moriguchi, Y., Imazeki, I., Ishikawa, Y., Ataka, K., Hasegawa, S., Ito Y., Higuchi, N., Kazama, J. J., Gejyo, F., and Miyazaki, J.-I. Continuous erythropoietin delivery by muscle-targeted gene transfer using in vivo electroporation, Hum. Gene Ther. 11, 429-437 (2000).

19. Widera, G., Austin, M., Rabussay, D., Goldbeck, C., Barnett, S. W., Chen, M., Leung, L., Otten, G. R., Thudium, K., Selby, M. J., and Ulmer, J. B. Increased DNA vaccine delivery and immunogenicity by electroporation in vivo, J. Immuno. 164, 4635-4640 (2000).

20. Li, S., Zhang, X., Xia, X., Zhou, L., Breau, R., Suen, J., and Hanna, E. Intramuscular electroporation delivery of IFN- $\alpha$ Gene Therapy for Inhibition of Tumor Growth Located at a Distant Site, Gene Ther. 8, 400-407 (2001).

21. Nishi, T., Yoshizato, K., Yamashiro, S., Takeshima, H., Sato, K., Hamada, K., Kitamura, I., Yoshimura, T., Saya, H., Kuratsu, J., and Ushio, Y. High-efficiency in vivo gene transfer using intraarterial plasmid DNA injection following in vivo electroporation, Cancer Res. 56, 1050-1055 (1996).

Date Received: February 28, 2002
22. Rols, M.-P., Delteil, C., Golzio, M., Dumond, P., Cros, S., and Teissie, J. In vivo electrically mediated protein and gene transfer in murine melanoma, Nat. Biotech. 16, 168-171 (1998).

23. Heller, L., Jaroszeski, M. J., Coppola, D., Pottinger, C., Gilbert, R., and Heller, R. Electrically mediated plasmid DNA delivery to hepatocellular carcinomas in vivo, Gene Ther. 7, 826-829 (2000).

24. Niu, G., Heller, R., Catlett-Falcone, R., Coppola, D., Jaroszeski, M., Dalton, W., Jove, R., and Yu, H. Gene therapy with dominant-negative Stat 3 suppresses growth of the murine melanoma B16 tumor in vivo, Cancer Res. 59, 5059-5063 (1999).

25. Lohr, F., Lo, D. Y., Zaharoff, D. A., Hu, K., Zhang, X., Li, Y., Zhao, Y., Dewhirst, M. W., Yuan, F., and Li, C. Y. Effective tumor therapy with plasmid-encoded cytokines combined with in vivo electroporation, Cancer Res. 61, 3281-3284 (2001).

26. Kishida, T., Asada, H., Satoh, E., Tanaka, S., Shinya, M., Hirai, H., Iwai, M., Tahara, H., Imunishi, J., and Mazda, O. In vivo electroporation-mediated transfer of interleukin-12 and interleukin-18 genes induces significant antitumor effects against melanoma in mice, Gene Ther. 8, 1234-1240 (2001).

27. Heller, L. C., Pottinger, C., Jaroszeski, M. J., Gilbert, R., and Heller, R. In vivo electroporation of plasmids encoding GMCSF and interleukin-2 into existing B16 melanomas combined with electrochemotherapy induces long term antitumor immunity, Melanoma Res. 10, 577-583 (2000).

28. Horton, H. M., Anderson, D., Hernandez, P., Barnhart, K. M., Norman, J. A., and Parker, S. E. A Gene Therapy for Cancer using Intramuscular Injection of Plasmid DNA Encoding Interferon $\alpha$, Proc. Natl. Acad. Sci. USA 96, 1553-158 (1999).

29. Gilbert, R., Jaroszeski, M. J., and Heller, R. Novel electrode designs for electrochemotherapy, Biochim. Biophys. Acta 1334, 9-14 (1997).

30. Lucas, M. L. and Heller, R. Immunomodulation by electrically enhanced delivery of plasmid DNA encoding IL-12 to murine skeletal muscle, Mol. Ther. 3, 47-53 (2001). 